\title{
Students With Intellectual Disabilities Going to College? Absolutely!
}

\author{
Harold L. Kleinert $\mid$ Melissa M. Jones $\mid$ Kathleen Sheppard-Jones, \\ Beverly Harp Elizabeth M. Harrison
}

In a pilot project in Kentucky, called SHEP, young people with intellectual disabilities are pursuing career goals and learning important life skills. They participate in college courses, work with mentors and coaches, and experience supported employment opportunities-all through partnerships among school systems, institutions of higher learning, and community agencies. For example, one student pursuing a career in graphic design works at a screen printing business while simultaneously taking college courses to pursue his career goal. This article describes the rationale for such programs, the scope of the programs, and benefits to students and the community.

Postsecondary education and students with intellectual disabilities have not historically been viewed as compatible. In fact, it was only with the 1977 implementation of the Education for All Handicapped Children Act (Public Law 94-142) that students with the most significant disabilities were guaranteed a public education at all, much less the opportunity to attend postsecondary programs. Yet with subsequent reauthorizations of IDEA, including the Individuals With Disabilities Education Act (IDEA) of 2004 (Public Law 108446), we have come to realize that all students should have the opportunity to learn age-appropriate academic content and engage in activities alongside their peers without disabilities. In this article, we propose a model of postsecondary education for students with intellectual disabilities (ID); this model extends the notion of inclusive education to the next level-going to college.

Though tremendous overall gains have occurred in the past 15 years in the percentage of students with disabilities who have attended some form of postsecondary education (Newman,
Wagner, Cameto, Knokey, \& Shaver, 2010), the lowest percentage of students from any disability category attending postsecondary education has been that of students with ID (Wagner, Newman, Cameto, Garza, \& Levine, 2005). Until recently, few educators or community members held expectations that students with ID would continue their education after high school. Indeed, the historical exclusion of students with ID from postsecondary experiences has played a significant role in the perpetuation of a cycle of low expectations and poor adult outcomes overall (Grigal, Hart, \& Paiewonsky, 2010).

In recent years, a growing number of colleges have offered opportunities for students with intellectual disabilities (Think College, 2011a). Students taking part in some of these programs are often dually enrolled by finishing their final years of high school in a college setting with the additional support 

Moreover, students with ID who participated in inclusive postsecondary education also reported increased satisfaction across several life domains, including emotional well-being, interpersonal relationships, personal development, self-determination, and social inclusion (Hughson, Moodie, \& Uditsky, 2006). For campus communities, the presence of students with ID offers invaluable opportunities for students to engage in learning alongside peers with different educational experiences and learning styles. For universities and colleges seeking to broaden the diversity of their student populations, the presence of students with ID adds to the campus and academic life for all students, incorporating opportunities for mentoring and friendships.

\section{The Higher Education Opportunities Act of 2008 (HEOA)}

The HEOA provides opportunities for students with ID who are enrolled in a Comprehensive Transition and Postsecondary Program (CTP) approved by the U.S. Department of Education, including eligibility for Pell Grants and Federal Work Study Programs. Whereas colleges and universities must first apply to offer a CTP, what is new to these programs is that students with ID may access such federal support (e.g., Pell Grants, Work-Study) if they are working toward an educational credential (not necessarily a degree), as specifically defined by the institution in its CTP application. This credential, which can reflect personalized student goals designed to address employment, independent living, and educational outcomes, can include audited courses (as well as for-credit courses), job internships, and other on-campus activities designed to lead to enhanced independence and employment. Most important, students with ID may qualify to participate in a CTP even if they do not have a standard high school diploma, or if they do not meet the requirements to enroll in a regular degree program at the institution. Figure 1 illustrates how the supports now available to students with ID under CTPs build on, and yet are dis- tinct from, the services and accommodations that an institution of higher education (IHE) must offer, under the requirements of Section 504 of the Rehabilitation Act of 1973, to all students with documented disabilities who enroll at that institution. (See Gil (2007) for a full explanation of the allowable supports under Section 504 for students with disabilities.)

\section{A National Network of Postsecondary Programs}

To further enable young adults with intellectual disabilities to gain access to, and complete postsecondary education, the HEOA authorized the funding of postsecondary Transition Programs for Students With Intellectual Disabilities (TPSID). Twenty-seven TPSID grants were awarded in the fall of 2010 to colleges and universities, or IHEs, around the United States. According to the U.S. Department of Education (2010), TPSIDs are funded to serve students with intellectual disabilities by providing individualized supports and services with respect to academic, social, and vocational goals.

\section{A National Resource: Think College}

In addition to providing competitive funding for the 27 different model programs, the TPSID initiative also authorized the Institute for Community Inclusion at the University of Massachusetts, Boston (www .thinkcollege.net) for colleges and universities that operates as a national clearinghouse for educators, students, and families regarding postsecondary education programs for students with ID. differently, they are often classified in terms of being stand-alone (separate), mixed, or integrated (Hart, Grigal, Sax, Martinez, \& Will, 2006). A stand-alone program, although located on a 2- or 4-year college campus, might offer specific classes aimed solely at students with ID. Such a program may also include a residential component for students to live away from home in dorms or apartments with other students. An integrated program uses existing coursework at the college or university so students with and without disabilities take classes together. The residential component would also be integrated with students without disabilities. A mixed program draws on aspects from both the stand-alone and integrated program types (e.g., separate coursework for students with intellectual disabilities but inclusion in residential life and extracurricular activities).

An example of an integrated approach, being applied from a statewide perspective, is the Supported Higher Education Project (SHEP) of Kentucky. The goal of SHEP, funded through a 5-year grant from the U.S. Office on Postsecondary Education as one of the TPSIDs, is to build capacity across colleges and universities in the state, so that students with ID have a choice of college programs. This project developed partnerships with key state agencies including the Kentucky Department of Education (KDE), the Kentucky Office of Vocational Rehabilitation (OVR), the Kentucky Division of Developmental and Intellectual Disabilities (DIDD), and the Commonwealth Council on Developmental Disabilities (CCDD).

\section{Interagency partnerships and the use of shared funding}

streams enable students with ID to attend college and choose careers, rather than only attending day programs or sheltered workshops.

\section{Types of Postsecondary Education Programs: What Do They Look Like?}

Though postsecondary programs for students with ID can be shaped quite
Interagency partnerships and the use of shared funding streams enable students with ID to attend college and choose careers, rather than only attending day programs or sheltered workshops. 

With Disabilities Under Section 504

\begin{tabular}{|c|c|c|}
\hline $\begin{array}{l}\text { Completion of regular } \\
\text { high school diploma }\end{array}$ & Required for college entrance. & $\begin{array}{l}\text { Students with ID may enroll in a CTP without a } \\
\text { regular high school diploma. }\end{array}$ \\
\hline $\begin{array}{l}\text { Pell Grants and } \\
\text { Federal Work-Study }\end{array}$ & $\begin{array}{l}\text { Students are eligible if they meet financial } \\
\text { means test and they maintain satisfactory } \\
\text { academic progress, as defined by the university } \\
\text { or college, for all students. }\end{array}$ & $\begin{array}{l}\text { Students with ID are eligible if they meet financial } \\
\text { means test and they maintain satisfactory } \\
\text { academic progress, as defined by the CTP within } \\
\text { that college or university. }\end{array}$ \\
\hline $\begin{array}{l}\text { Reasonable } \\
\text { accommodations }\end{array}$ & $\begin{array}{l}\text { Students with documented disabilities have the } \\
\text { right to reasonable accommodations to ensure } \\
\text { academic access, but such accommodations } \\
\text { cannot alter the course content or objectives. }\end{array}$ & $\begin{array}{l}\text { Students with ID also have the right to reasonable } \\
\text { accommodations to ensure academic access, } \\
\text { including courses not taken for credit. }\end{array}$ \\
\hline Course modifications & $\begin{array}{l}\text { Students are not eligible for course } \\
\text { modifications. }\end{array}$ & $\begin{array}{l}\text { If taking courses for audit, and with permission } \\
\text { of the instructor, students with ID may have } \\
\text { course modifications that do alter the course } \\
\text { content to meet their individualized learning } \\
\text { objectives. Audited courses can count towards the } \\
\text { CTP certificate. }\end{array}$ \\
\hline Advising & $\begin{array}{l}\text { Students participate in advising in the same } \\
\text { fashion as all other students on campus. }\end{array}$ & $\begin{array}{l}\text { CTP must include an advising and curriculum } \\
\text { structure for enrolled students that is a part of the } \\
\text { campus advising structure for all students. }\end{array}$ \\
\hline
\end{tabular}

The partnership with the state vocational rehabilitation agency led to a pilot project for several of the SHEP students. The intent is for students to gain college experiences and exposure to life skills and knowledge through coursework paired with internships or work study opportunities. The expectation is for gainful employment in a field that is meaningful to the individual. The pilot project is structured around (a) the development of a relevant course of study, (b) the use of academic/employment coaches to coordinate individualized supports, (c) the development of peer and natural supports, (d) an involvement in extracurricular and campus activities, and (e) access to financial supports. Currently, seven students are involved in the pilot program; five of the seven are taking postsecondary classes and working part-time. SHEP staff work with supported employment agencies to ensure that each student learns objectives related to his or her internship or work study, that progress is systematically documented, and any gaps in supports are identified. For example, one student pursuing a career in graphic design works at a screen printing business while simultaneously taking college courses to pursue his career goal.

In addition to the seven students participating in the SHEP supported employment pilot, SHEP is working with 30 additional students, who are enrolled in classes or preparing to enter college. Some of the courses students have taken (either for credit or on audit basis) include Introduction to Information Systems, Introductory Art, Beginning Web Design, Foundations of College Writing, Introduction to Computers, Experiential Education, Introduction to Graphic Design, 
Pre-Algebra, and Basic Algebra With Measurement.

\section{Keys to Success}

One of the greatest barriers to creating inclusive campus communities are the attitudes and preconceived notions about the limited ability of students sible, past and present peer supports. Invitations can also be extended to staff members in formalized support roles such as vocational rehabilitation counselors, professors, and disability service personnel, as warranted.

A variety of processes can be used to facilitate this collaborative effort of

\section{Signs of meaningful involvement in campus life include helping out with a collegiate sports team, participating in intramurals, engaging in campus events, attending campus theater productions, volunteering, joining clubs, and simply eating lunch with peers.}

with ID to meaningfully contribute to the collegiate environment. Through SHEP we strive to create an environment where other members of the university community recognize students with ID as members of the community who can actively contribute and participate. Signs of meaningful involvement in campus life include helping out with a collegiate sports team, participating in intramurals, engaging in campus events, attending campus theater productions, volunteering, joining clubs, and simply eating lunch with peers at the usual campus hangouts. By setting the stage through a coordinated set of practices geared toward communication and collaboration, the barriers created by historical biases and misinformation can be effectively dismantled.

\section{An Individualized Support Model}

Maintaining a focus on an "inclusive individual support model” (Hart et al., 2006, p. 1), planning should be student centered and individualized, based on the talents, strengths, and interests of each student with ID. Using a personcentered planning approach (O’Brien \& O'Brien, 2002) for each SHEP student, small teams who have a stake in the inclusive outcomes work together to identify the student's dreams, future goals, skills upon which to build, possible supports, and action steps with agreed upon timelines. In most cases, the teams consist of the student, her or his parent(s), the coordinator of the inclusive initiative, and whenever pos- customizable supports including Planning Alternative Tomorrows With Hope (PATH; Pierpoint, O’Brien, \& Forest, 2011), the McGill Action Planning System (MAPS; Kellems \& Morningstar, 2010), or Supporting Social Roles (SSR) scales (O'Brien, 2010). The end result should be a clearly articulated picture of the goals for participation in college, as well as action steps for achieving those goals including academic, career, and social activities. (See Figure 2 for an example of a PATH for one of the students in the SHEP program.) Person-centered planning for postsecondary education can (and should) start while students are in high school. Whereas Figure 2 illustrates a PATH for a student enrolled in college, this process is equally valid for IEP transition teams in high school to ensure that a student has all of the necessary supports in place before he enrolls in college.

\section{Peer Mentors}

Peer mentors can play a vital role in supporting students with ID on campus. A peer mentor is another college student who agrees to support the student with ID to successfully navigate the campus culture such as supporting a student to actively engage in a class, tutoring, academic coaching outside of class, and socializing either on or off campus (Jones, Weir, \& Hart, 2011). When developing peer mentoring programs, remember that "mentors are not born but developed” (Ramani, Gruppen, \& Kachur, 2006, p. 404), and peer mentor development is an evolving process. Therefore, providing the necessary mentor training is imperative to assure the mentors understand what is expected of them from the start. Each mentor will gain skills in collaboration and accommodation along the way, but starting with some level of confidence enhances the mentoring relationship. Most important, the foundation of an effective mentoring partnership is equality between the mentor and mentee, with each learning and gaining skills as a result of interacting with the other (Stoddard, 2003; Zachary, 2005). To maintain parity in the relationship, mentoring partners should prioritize socializing and fun as much as they do academics, with fun being the equalizer in the partnership.

Through SHEP, we found it helpful to provide course or project credit for mentoring to increase accountability and consistency on the mentor. Formal peer mentors, however, are not the only option when creating a supportive environment. The occurrence of natural supports, students in the same class simply stepping up and offering or agreeing to provide assistance when needed, is a growing trend in many college classes. When this occurs, the dream of an inclusive culture is realized. These natural supports can be cultivated in the high school setting as peers who plan on attending the same college or university as the student with ID are identified, and connections are nurtured while the students are still in high school.

Mentoring partnerships between mentors and mentees need to be supportive relationships, in which both parties understand the boundaries of a friendship. It is the expectation that mentoring partners, whether in high school or college, honor one another and treat each other with the utmost respect. Maintaining trust is crucial in every relationship and the mentors must learn the importance of confidentiality and also understand that what the mentoring partner tells them should be treated as confidential unless there is a clear responsibility for sharing that information. Mentors are expected to (a) commit to a mentoring 


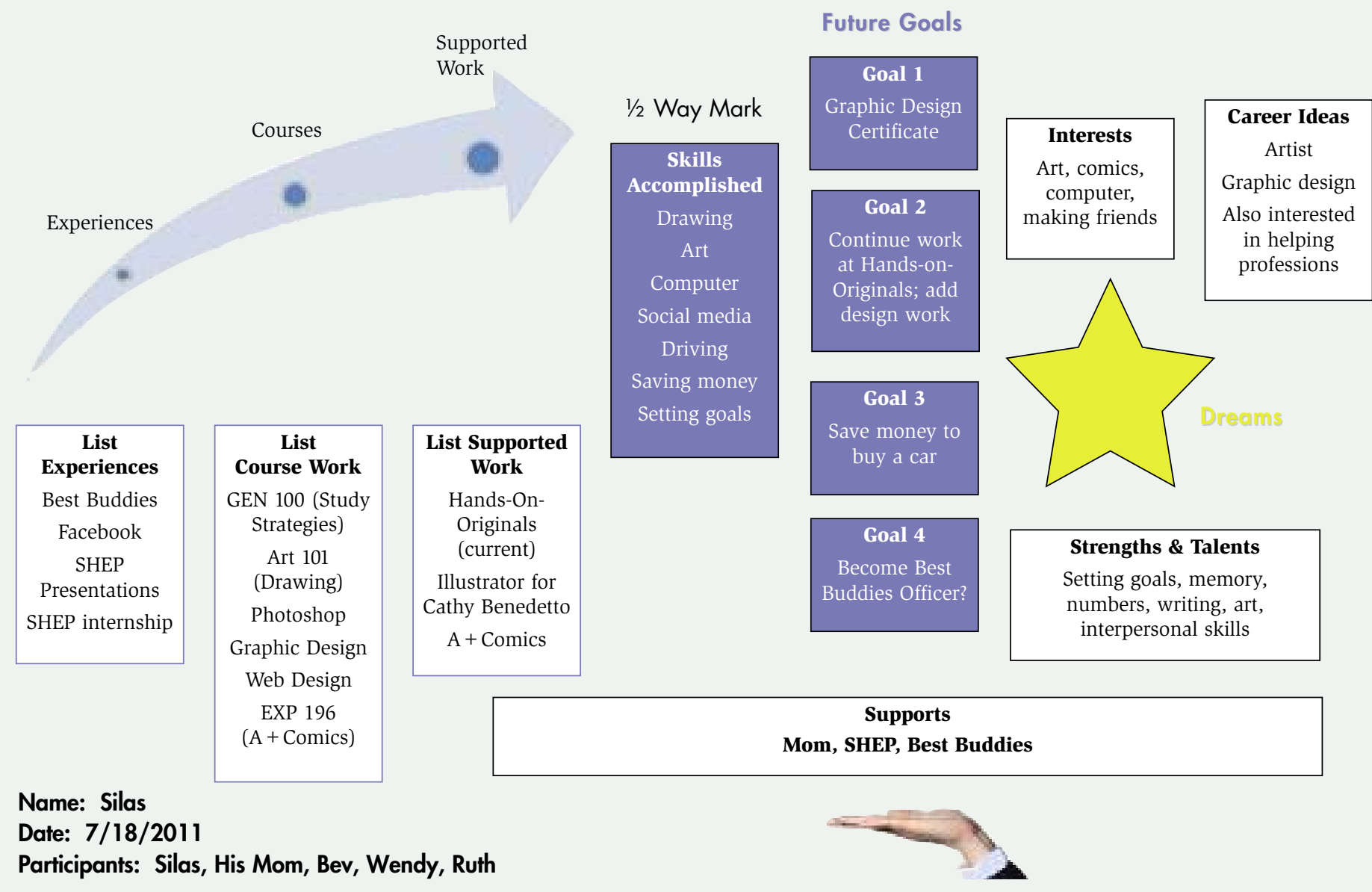

Note. PATH $=$ Planning Alternative Tomorrows With Hope; SHEP $=$ Supported Higher Education Project.

schedule; (b) introduce themselves to the course instructors ahead of time;

(c) provide support in the classroom in the least intrusive manner possible; and (d) look for opportunities to build upon their mentee's strengths and interests through extracurricular activities, campus events, and organizations (for more information on mentor responsibilities see www.shep.org). These strategies are very similar to peer-support strategies (Carter, Cushing, \& Kennedy, 2009) that are effective in supporting high school students with significant disabilities in general education classes and other school activities.

\section{Working With Local Colleges to Develop New Programs}

As educators of students with intellectual disabilities approach colleges and other postsecondary programs about the possibility of students with ID attending, there are a few questions we have found that college administrators nearly always ask. Here are some of the most frequently asked questions (FAQs), as well as responses we found effective.

\section{FAQs}

- What is the benefit for students with ID to attend college? Although we have tried to answer this question throughout this paper (e.g., enhanced employability in chosen career or opportunities for developing increased social and life skills), we have found it helpful to also emphasize that the presence on campus of individuals with ID can be a key element in embracing diversity. Disability is a natural part of the human experience, and the presence of individuals who have different gifts and challenges enriches the campus environment.

- Won't a CTP program create inordinate work for our faculty, who are already overburdened by numerous demands in their work? Answers we have given to this question include (a) having students initially enroll in courses in which the instructor explicitly consents to participate in the CTP, (b) offering both training and ongoing support to participating faculty, and (c) working with college students who wish to mentor students with ID in courses and other campus activities. We discussed with both administrators and faculty that mentorship can be a valuable service learning or field experience for students from a variety of disciplines. 


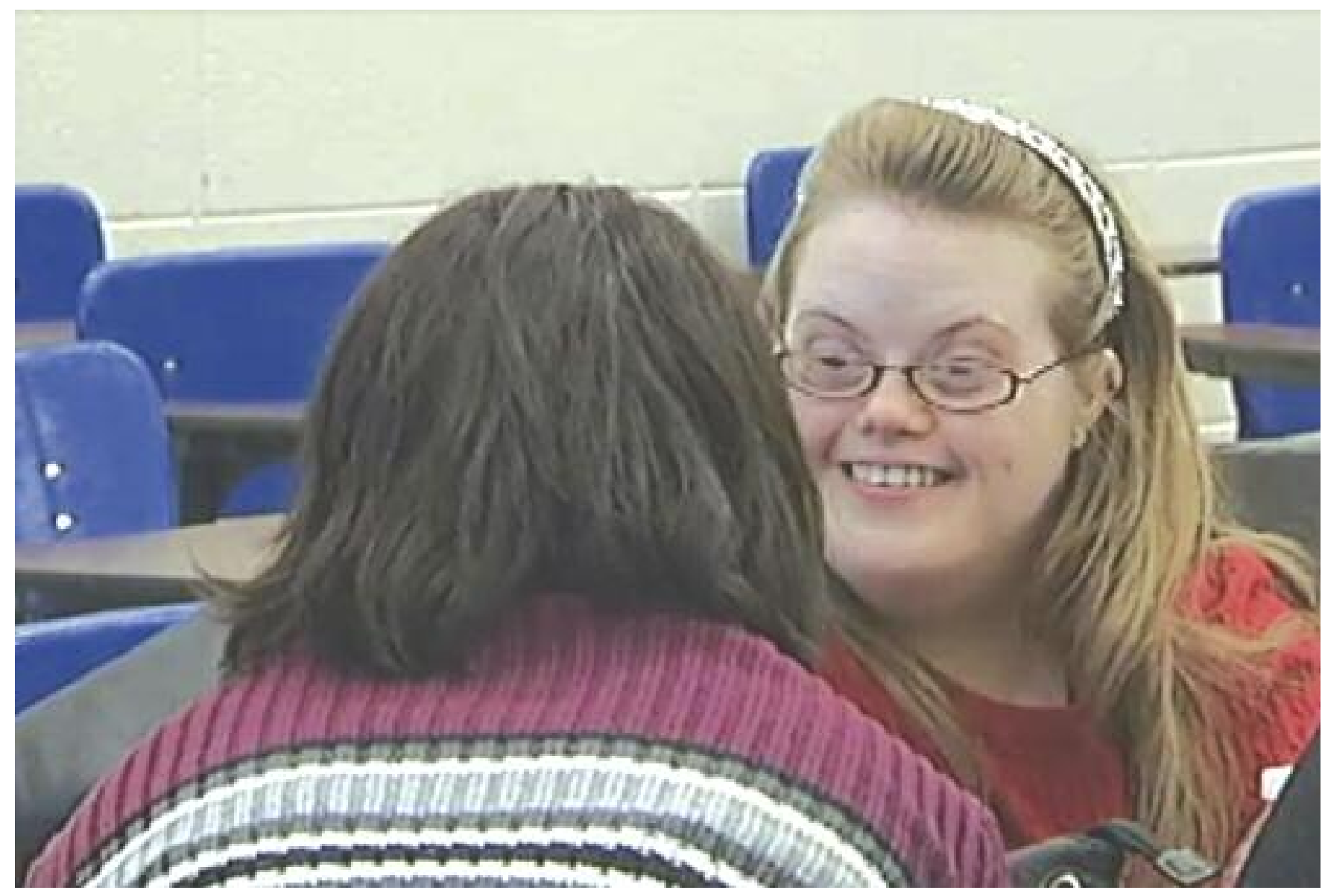

- Is it fair to provide course modifications (i.e., modifications in course content) to students with ID when other students have to master all of the content? If students with ID are auditing a class as part of their CTP credential, then they are not receiving official university credit, and it is reasonable to modify course content, in collaboration with the course instructor. However, if a student with ID is taking the course for credit, then that student must attempt to master all of the material which other students are expected to learn, receiving reasonable accommodations to do so. In this instance, course content would not be altered.

\section{Two Student Examples}

Jillian. Jillian is a 21-year-old college student attending classes part time. She enjoys staying active and would love to teach young children. She started on this career path through her paid summer job at a local preschool and volunteer work in the Early
Childhood Center of the university she attends. She studies hard and is a diligent student, with professors exclaiming they wish all their students were as committed to learning as Jillian.

Jillian works with peer mentoring partners who support her inclusion in both the campus culture and the community. She receives assistance with note-taking, determining key points from lectures and texts, and studying, but otherwise is a very self-sufficient and independent young woman. Although Jillian is enrolled in college as a non-degree-seeking student and audits her classes, she consistently strives to do her best to gain knowledge and skills from each of her courses. Each semester, her mother, past and present mentoring partners, the program coordinator, and Jillian meet to discuss Jillian's progress toward her goals, review her semester schedule, and determine what types of supports they believe she will need to fully benefit from her college classes and experiences. Timelines are reviewed and mentoring plans are revised accordingly.

As many college students do, Jillian balances her academic coursework with the demands of a part-time job. As an assistant manager for the men's collegiate basketball team, Jillian is required to attend all practices and home games during the season. Her responsibilities include running the warm-up sessions for players and managing the equipment during games and practices. As one member of the team explained, "She knows how to find the good in everything. I probably play the least of anyone on the team, but she still manages to make me feel like the star player. I love her for that.”

(Donaldson, 2011, p. 23). Through this experience, Jillian has multiple opportunities to meet new people, engage socially with other college students, and be a valued and contributing member of a group on campus.

When Jillian was in elementary and high school, her parents made sure she was always included in the general education environment, even though 
she received special education services. As an individual with Down syndrome and ID, Jillian inadvertently challenged notions of inability through her determination, the same determination demonstrated on the university campus. As Jillian stated, “Don't give me the answers, just read the questions. I can answer them myself." Her success is not measured by a passing test grade, but rather by her independence, persistence, self-advocacy, and belonging as related to her personal goals for attending college.

Silas. From a young age, Silas had known he wanted to attend college. Because he had received special education services and had been diagnosed with ID, few people believed that he would attain this goal. His mother struggled with teachers who did not understand how to accommodate his learning styles and with a vocational counselor who proclaimed that Silas would not be able to work. Silas never gave up on himself or his quest to be "the ultimate artist." After high school, he continued to volunteer at his former school's office. There he learned of a new pilot project that might help him find his place in higher education.

With art as his leading interest, Silas enrolled in a Photoshop course at a community college. He earned an "A" in the course and subsequently took classes in graphic design, drawing, and an academic skills program. He gained general business skills through an experiential education course and he earned credit by working in a local comic book store. In his third semester, Silas was recruited to illustrate a science fiction book by a local author. Now a participant in the SHEP program, Silas is employed at a screen print business where he assists with the production of t-shirts 3 days a week. His employers are impressed by his dependability and work ethic and have offered him the opportunity to work with one of their graphic designers for an hour each day before beginning his regular duties.

SHEP staff members meet regularly with Silas to discuss plans for the future, provide tutoring, and encourage his ever-growing independence. Since beginning his journey to college, Silas became a member of the workforce, maintained a 3.5 grade point average, earned his driver's license, developed many friendships, and become a great advocate for other students with disabilities. He participates in the campus Best Buddies Program, in which students with ID are matched with other students on campus, and he is considering becoming an officer in that program. He believes that "people with disabilities will always succeed with the patience and help of friends, [supportive staff], and family." See Figure 2 for Silas's PATH, indicating his goals and his plans for achieving them.

\section{Implications for Teachers}

New postsecondary education opportunities for students with ID have tremendous implications for goal setting and transition planning that IEP teams should prioritize with students. Along with the specific IDEA transition requirements for students to learn about and explore postsecondary opportunities, the reality that students with ID are actually attending colleges and universities should compel IEP ered as self-advocates, gain a better understanding of their abilities, and take a greater ownership of their own IEP meetings (Jones, 2006; Test et al., 2004). These skills should be taught and nurtured early in a student's school career, embedding skill development for fostering self-determination in elementary school, leading toward meaningful engagement of students in their IEPs at least by the time the students enter high school.

Aside from a focus on self-determination and self-advocacy, elementary and secondary teachers, from preschool to 12 th grade, also need to ensure that students have the necessary supports for involvement in preferred extracurricular activities $(\mathrm{H}$. Kleinert, Miracle, \& Sheppard-Jones, 2007) including opportunities for community and service learning, academic clubs (e.g., Foreign Language, Yearbook, or Future Farmers of America), and special interest clubs (e.g., Photography and Computer), to develop the confidence and skills to continue these activities in college or other postsecondary settings. Through meaningful involvement in these activities, stu-

\section{Moving beyond exploration to a focus on problem solving and increased independence has become a necessity as possibilities open for students with ID.}

teams to prepare students for such experiences. As noted earlier, teachers can institute such person-centered planning processes as PATH (see Figure 2), to help students prepare for the transition to postsecondary education.

Moving beyond exploration to a focus on problem solving and increased independence has become a necessity as possibilities open for students with ID. Students with ID are not limited to traditional structured employment and leisure activities; it is critical that teachers start early in teaching self-advocacy skills to students with ID (J. Kleinert, Harrison, Fisher, \& H. Kleinert, 2010). In preparation for postsecondary education in which students must direct their own learning, students need to be empow- dents with ID develop socialization and problem-solving skills necessary for inclusive experiences on a college or university campus. In many instances, we have found the social aspect of college to be even more important for promoting student growth and independence than the academics.

Teachers also need to ensure that students with ID have access to the grade-level general curriculum. Strategies to enable students to understand more complex academic content and build valued social relationships, including peer-support strategies (Carter et al., 2009) are important, so that when learning new things together they can provide both academic and social supports to their peers with significant disabilities. Many of the col- 
lege students who volunteer to mentor a peer with a disability describe having a similar mentoring experience while still in high school. Fostering relationships such as these early on helps students recognize the benefits of interacting with others of varying ability and paves the way for the development of natural supports on a college campus.

Access remains a daunting barrier to many students with ID who wish to continue their formal learning beyond high school. Institutions of higher education are becoming increasingly technologically savvy, requiring students to enter college with more than basic skills in accessing and using technology. Beyond the required technology, however, is also the need for high school students with ID to have access to and experience with the assistive technology necessary for academic success in college, such as the use of iPAD applications that combine the power of augmentative communication systems with word-processing capabilities for college assignments.

Finally, like all high school students who are planning their futures, students with ID need the opportunity to receive assistance from school guidance counselors, specifically trained in helping students to identify sources of financial aid and college opportunities to address their career goals. Awareness of the resources students need to independently negotiate college expectations is paramount for contemporary IEP transition teams. Otherwise, valuable learning opportunities are lost, stunting the potential growth of young adults with ID.

\section{Final Thoughts}

Times are changing, as evidenced through the myriad of opportunities that now exist nationwide for students with disabilities, particularly students with ID. Thirty-five years ago, advocates fought for students with disabilities to have a right to a $\mathrm{P}-12$ education; now we are talking about students with ID meaningfully participating in institutions of higher education. In recognition of these changes, intervention specialists can now begin assisting IEP teams in imagining what a postsecondary experience might look like for a student, and start the planning process, working toward this possibility.

In this article we have described the new opportunities for postsecondary education available to students with ID through the Higher Education Opportunities Act of 2008. We have also attempted to describe why these opportunities are important to students with ID, and key strategies for ensuring that their college experience is an important next step to a valued career, new friendships and interests, and ultimately, a fulfilling life. Indeed, these are the things we want for all students!

\section{References}

Carter, E., Cushing, L., \& Kennedy, C. (2009). Peer support strategies for improving all students' social lives and learning. Baltimore, MD: Brookes.

Donaldson, B. (2011). Jillian the magnificent: Meet NKU's guardian angel maker. Northern Magazine, 9(2), 20-23.

Gil, L. (2007). Bridging the transition gap from high school to college. TEACHING Exceptional Children, 40(2), 12-16.

Grigal, M., Hart, D., \& Paiewonsky, M. (2010). Postsecondary education: The next frontier for individuals with intellectual disabilities. In M. Grigal \& D. Hart (Eds.), Think college: Postsecondary education options for students with intellectual disabilities (pp. 1-28). Baltimore, MD: Brookes.

Hall, M., Kleinert, H., \& Kearns, J. (2000). College connection: New directions in post-secondary programs for students with moderate and severe disabilities. TEACHING Exceptional Children, 32(3), 58-65.

Hart, D., Grigal, M., Sax, C., Martinez, D., \& Will, M. (2006). Postsecondary education options for students with intellectual disabilities, Research to Practice, 45, 1-4. Retrieved from http://www.thinkcollege .net/for-professionals/pathways-to-postsecondary-education

Higher Education Opportunities Act of 2008, Public Law 110-315, 20 U.S.C. §§ 1001 et seq.

Hughson, E. A., Moodie, S., \& Uditsky, B. (2006). The story of inclusive post secondary education in Alberta: Final research report 2004-2005. Retrieved from http:// www.steps-forward.org/The_Story_of_ Inclusive_Post_Secondary_Education_in Alberta.pdf

Individuals With Disabilities Education Act (IDEA) of 2004, Public Law 108-446, 20 U.S.C. §§ 1400 et seq.

Jones, M. (2006). Teaching self-determination: Empowered teachers, empowered
Students. TEACHING Exceptional Children, 39(1), 12-17.

Jones, M., Weir, C., \& Hart, D. (2011). Impact on teacher education programs of students with intellectual disabilities attending college, Insight: A Think College Brief on Policy, Research, \& Practice, 6. Retrieved from http://www .thinkcollege.net

Kellems, R., \& Morningstar, M. (2010). Tips for transition. TEACHING Exceptional Children, 43(2), 60-68.

Kleinert, H., Miracle, S., \& Sheppard-Jones, K. (2007). Including students with moderate and severe disabilities in extracurricular and community recreation activities: Steps to success! TEACHING Exceptional Children, 39(6), 33-38.

Kleinert, J., Harrison, B., Fisher, T., \& Kleinert, H. (2010). "I can and I did"Self-advocacy for young students with developmental disabilities. TEACHING Exceptional Children, 43(2), 16-26.

Migliore, A., Butterworth, J., \& Hart, D. (2009). Postsecondary education and employment outcomes for youth with intellectual disabilities. Think College Fast Facts, 1. Retrieved from http://www .thinkcollege.net

Moon, M. S., Grigal, M., \& Neubert, D. (2001). High school and beyond: Students with significant disabilities complete high school through alternative programs in post-secondary settings. Exceptional Parent, 31(7), 52-57.

Newman, L., Wagner, M., Cameto, R., Knokey, A., \& Shaver, D. (2010). Comparisons across time of the outcomes of youth with disabilities up to 4 years after high school. A report of findings from the National Longitudinal Transition Study (NLTS) and the National Longitudinal Transition Study-2 (NLTS2) (NCSER 20103008). Menlo Park, CA: SRI International.

O’Brien, J. (2010). Supporting social roles: A second bottom line for services to people with developmental disabilities. San Francisco, CA: Creative Commons. Retrieved from http://www.inclusion .com

O’Brien, J., \& O'Brien, C. L. (Ed.). (2002). Implementing person-centered planning: Voices of experience. Volume II. Toronto, ON: Inclusion Press.

Pierpoint, J., O’Brien, J., \& Forest, M. (2011). Path: Planning possible positive futures: Planning alternative tomorrows with hope (2nd ed.). Toronto, ON: Inclusion Press.

Ramani, S., Gruppen, L., \& Kachur, E. K. (2006). Twelve tips for developing effective mentors. Medical Teacher, 28, 404408. doi:10.1080/01421590600825326

Stoddard, D. A. (2003). The heart of mentoring: Ten proven principles for developing people to their fullest potential. Colorado Springs, CO: NavPress. 
Test, D., Mason, C., Hughes, C., Konrad, M., Neal, M., \& Wood, W. (2004). Student involvement in individualized education program meetings. Exceptional Children, 70, 391-412.

Think College. (2011a). Postsecondary education initiatives for students with intellectual disabilities. Retrieved from http://www.thinkcollege.net /databases/programs-database? view $=$ programsdatabase

Think College. (2011b). Should I even think about college for my son or daughter? Retrieved from http://www.thinkcollege .net/for-families

U.S. Department of Education. (2010). Transition and postsecondary programs for students with intellectual disabilities. Retrieved from http://www2.ed.gov /programs/tpsid/index.html

Wagner, M., Newman, L., Cameto, R., Garza, N., \& Levine, P. (2005). After high school: A first look at the postschool experiences of youth with disabilities. A report from the National Longitudinal Transition Study-2 (NLTS2). Menlo Park, CA: SRI International. Retrieved from www.nlts2 .org/reports/2005_04/nlts2_report_2005 _04_complete.pdf.

Zachary, L. J. (2005). Creating a mentoring culture: The organization's guide. San Francisco, CA: Jossey-Bass.

Harold L. Kleinert (Kentucky CEC), Executive Director, Human Development Institute, University of Kentucky, Lexington. Melissa M. Jones (Kentucky CEC), Associate Professor of Special Education, Department of Teacher Education, Northern Kentucky University, Highland Heights. Kathleen Sheppard-Jones, Training Director, Human Development Institute; Beverly Harp, Postsecondary Program Specialist, Supported Higher Education Project, Human Development Institute; and Elizabeth M. Harrison, Principal Investigator, Supported Higher Education Project, Human Development Institute, University of Kentucky, Lexington.

Address correspondence concerning this article to Harold L. Kleinert, Human Development Institute, University of Kentucky, 126 Mineral Industries Building, Lexington, $K Y$ 40506-0051 (e-mail: hklein@uky.edu).

This article was supported in part by a grant from the U.S. Department of Education Office of Postsecondary Education Programs (Grant P407A100005). However, the opinions expressed do not necessarily reflect the position or policy of the Office of Postsecondary Education Programs, and no official endorsement should be inferred.

TEACHING Exceptional Children, Vol. 44, No. 5, pp. 26-35.

Copyright 2012 CEC

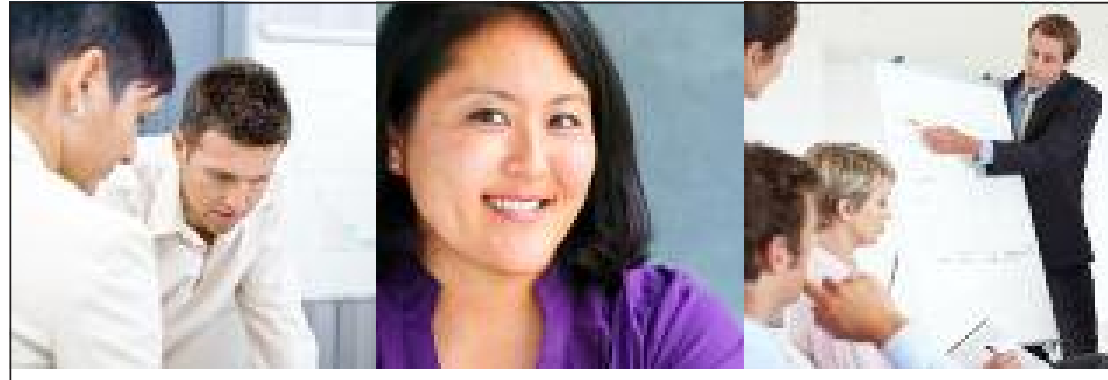

CHOOSE CHAPMAN EARN a GRADUATE DEGREE from the COLLEGE of EDUCATIONAL STUDIES

Exploring new ways to think about, educate and support exceptional students who learn differently is a foundational principle of Chapman University's College of Educational Studies.

\section{YOU CAN PURSUE A MASTER'S DEGREE IN:}

- TEACHING

- SPECIAL EDUCATION

- SCHOOL COUNSELING (PCC Certificate, starting fall 2012)

- SCHOOL PSYCHOLOGY (PCC Certificate, starting fall 2012)

- COMMUNICATION SCIENCES AND DISORDERS

\section{CHAPMAN ALSO OFFERS A PH.D. IN EDUCATION, WITH AN EMPHASIS IN DISABILITY STUDIES OR SCHOOL PSYCHOLOGY}

Chapman University delivers a uniquely personalized and comprehensive educational experience to highly qualified students. Our programs encourage innovation, creativity and collaboration, and focus on developing global citizen-leaders who are distinctively prepared to enhance education, teaching, leadership development and society.

Choose Chapman and discover the difference a graduate degree from Chapman University will make in your life - and in the lives of those around you. Financial aid is available. Take the first step and visit www.chapman.edu/CES/programs/grad.

\section{$\triangle$ CHAPMAN COLLEGE OF $\triangle$ UNIVERSITY EDUCATIONAL STUDIES} chapman.edu | Orange, CA 92866

Accredited by the Teacher Education Accreditation Council, the Commission on Teacher Credentialing the American Speech-Language-Hearing Association, the Commission on Accreditation of Athletic Training Education and the Western Association of Schools and Colleges. Chapman's College of Educational Studies is a member of the National Association of School Psychologists. 